\title{
Letters
}

\section{Medicolegal certificates in investigations of asylum applications}

SIR

According to the Swedish Immigration Board (SIB), about 26,500 people per year have applied for asylum in Sweden during the last decade. Experiences from Denmark show that up to $20 \%$ of those who seek asylum have been subjected to torture or severe illtreatment in their home countries. Since 1992, most of these applicants have been examined at the Centre for Torture and Trauma survivors (CTD) in Stockholm. ${ }^{2}$ The findings are described in medicolegal certificates submitted to the immigration authorities.

The present study was primarily aimed at analysing the relationship between the medicolegal certificates and the chances of obtaining asylum in 52 randomly selected CTD cases from the years 1994-96. The medicolegal certificates were classified according to extent of compatibility between testimony and physical evidence. In the first category, designated "informative", the clients often had no more than a few non-specific scars "consistent with torture". The second category was designated "supportive" of torture. These clients frequently had many scars and other objective evidence and gave a detailed and compatible testimony of torture.

The strength of evidence in support of torture described in the medicolegal certificates was analysed in relation to the decisions made by the Swedish Immigration Board and the Alien Appeals Board, where asylum applicants may appeal a negative decision. Other variables studied were findings of post traumatic stress disorder (PTSD) and suicide risk, and a number of social circumstances with possible influence on the outcome.
Twenty-eight of the 52 medicolegal certificates were "supportive" and 24 "informative". Thirty applicants (5 $\%$ ) were eventually granted residence permits, but only four of them $(8 \%)$ were granted asylum; two with a "supportive" medicolegal certificate and two with "informative" certificates, but only after referral to the United Nations Centre of Human Rights (UNCHR).

The other motivations for granting residence permits were of three kinds: 1) $17 \%$ of the 30 successful applicants were classified as "de facto refugees" (a category removed from the legislation in 1996), meaning that the applicant does not fulfil all the requirements for political asylum; 2) 53\% were allowed to stay for humanitarian reasons, and 3) $17 \%$ because of family ties.

A majority (53\%) of the 30 people granted residence permits had "supportive" medicolegal certificates. There was no statistically significant association between the motivations given by the authorities and the formulations (supportive or informative) in the medicolegal certificate $(\alpha$ square $\mathrm{p}$-value $>0.05$ )

Furthermore, CTD investigations were described as crucial to the decisions in only $14 / 52$ cases $(26 \%)$.

Mental health was evaluated by a psychiatrist in 47 cases, 37 of whom $(78 \%)$ were found to suffer from post traumatic stress disorder. There was no statistical association between the PTSD diagnosis and outcome of the asylum application $(\chi$ square $\mathrm{p}>$ $0.05)$. Neither was an impending risk of suicide, as registered in $14 / 33$ cases $(27 \%)$, significantly associated with the authorities' decisions ( $\chi$ square $p>$ 0.05 ). The only social and circumstantial factor statistically associated with a positive verdict was to have relatives already living in Sweden $(p<0.05)$.

In conclusion: the CTD examinations of alleged torture are meant to give reliable and unbiased information to the Swedish authorities involved, but the certificates provided are appar- ently often ignored. One reason may be lack of validation of the certificates, which is a considerable problem as absolute truths rarely can be demonstrated. Application of statistical probability methods and double-blind interview techniques might increase the validity of the medicolegal certificates. However, so far only a few studies have taken up this problem. ${ }^{3}$ Another possible explanation is that the Swedish Immigration Board as well as the Alien Appeals Board are political, not judicial, institutions, and thus may lack the competence correctly to evaluate medicolegal certificates that are normally intended for use in the courts.

\section{References}

1 Montgomery E. Refugee children from the Middle East. Scandinavian fournal of Social Medicine 1998;54, suppl: $1-152$.

2 Edston E. Superficial physical evidence may reveal torture; 5 years'experience f torture documentation. Läkartidningen 1999;96:628-31 (in Swedish bstract in English).

3 Montgomery E, Foldspang A. Criterion-related validity of screening for exposure to torture. Danish Medical Bulletin 1994;41:588-91.

LINA FORSMAN AND ERIK EDSTON $\mathrm{MD}, \mathrm{PhD}$ Department of Forensic Medicine, Umeå University, Umeå, Sweden and Department of Forensic Medicine, Linköping University, Linköping, Sweden, respectively

\section{Ethical ethics committees?: a response}

SIR

Following Dr Barber's letter ${ }^{1}$ relating to the mechanism for approval of Local Research Ethics Committees (LRECs), I have also had concerns over the intense pressure for a fast turn around for local approval. Projects may have been six months or more in the Multicentre Research Ethics 
Committee (MREC) process and then arrive on my desk with multiple telephone calls requiring turn around in a few days. Frequently researchers are not even aware of the number of copies we may require for perusal, and getting administrative details correc causes further delays.

If the process is to be truly ethical I believe that it must be performed with an appropriate number of people, always including a lay person, who, except in exceptional circumstances, should be in the same room together to get optimum examination of the issues. In addition, my understanding of the Good Clinical Practice (GCP) guidelines is that committees should do their business primarily by meet- ing. When our committee has spent considerable time developing standing procedures in conformity with guidelines and our own consciences, surely these should not be set aside on a case by case basis?

Members of the committee cannot override their normal commitments (particularly lay members who do not work for the National Health Service) instantaneously, and a considered response requires a certain amount of time. This is likely to be particularly pertinent in District General Hospitals where research is not the focus of the trust. I would not support excessive delays, but in my opinion, from the comments made to me by researchers, I feel that there are times when I am called upon to make up for delays elsewhere in the system. If MREC applications are to pass through LRECs (and I do mean if) then they cannot be considered as a rubber stamp, but must fulfil their collective ethical responsibility.

\section{Reference}

1 Barber SG. Ethical ethics committees? [letter]. Fournal of Medical Ethics [letter]. Fourn

$$
\begin{array}{r}
\text { DR G J TILDSLEY } \\
\text { Consultant Pathologist, } \\
\text { The Princess Royal Hospital, } \\
\text { Haywards Heath, } \\
\text { West Sussex } \\
\text { RH16 4EX }
\end{array}
$$

